\title{
W jaki sposób równoważyć wymagania i zasoby w pracy oraz ustanawiać jej granice? - o potrzebie personalizacji (w) pracy menedżerów
}

\author{
AgnieszKa WojtcZuk-Turek \\ Instytut Kapitału Ludzkiego, Szkoła Główna Handlowa w Warszawie
}

\begin{abstract}
Celem artykułu jest scharakteryzowanie wymagań wobec menedżerów oraz ich zasobów w kontekście funkcjonowania zawodowego, a także sformułowanie rekomendacji w zakresie sposobów ich równoważenia. Analizę i opis oparto na badaniach jakościowych przeprowadzonych z przedstawicielami firm pochodzących z przedsiębiorstw o zróżnicowanych branżach i wielkości. Na podstawie pogłębionych wywiadów jakościowych (IDI) stwierdzono zmiany w funkcjonowaniu lidera, łączącego wiele ról i działającego elastycznie, doświadczającego znacznej integracji granic pomiędzy sferą funkcjonowania prywatnego i zawodowego, skutkującej zmniejszonym work-life balance, oraz dużych przeciążeń wymaganiami w pracy. Sformułowano rekomendacje dotyczące zwiększania personalizacji w pracy jako sposobu na lepsze dopasowanie pracy do preferencji, pozwalającego na osiąganie zrównoważenia wymagań wobec pracowników i ich zasobów.
\end{abstract}

Słowa kluczowe: wymagania, zasoby, work-life balance, personalizacja w pracy

Kod klasyfikacji JEL: M12 


\section{W prowadzenie}

Koncentrowanie się przedsiębiorstw na wydajności pracy, właściwe dla podejścia stricte ekonomicznego, opartego na paradygmacie racjonalności, użyteczności i maksymalizacji korzyści, zakłada eskalację wymagań (np. systemy wysoce efektywnej pracy - HPWS). Zjawisko to można odnieść do sygnalizowanego w dyskursie naukowym poszukiwania zasobów wydajności, co trafnie oddaje stwierdzenie, że: „nowoczesne teorie i metody zarządzania poszukiwały rezerw wydajności i dynamicznego rozwoju nie w wytyczaniu granic, a w ich przekraczaniu" (Romanowska, Cygler, 2014, s. 13). Owe granice - ich przesuwanie czy przepuszczalność - mogą w sposób metaforyczny obrazować nasilenie zjawisk związanych z wykonywaniem pracy, do których zalicza się: intensyfikację, złożoność, upodmiotowienie czy „pracę bez granic" (Kubicek, Korunka, 2017; Murphy, Tierney, 2020). Badanie konsekwencji tych zjawisk - zarówno pozytywnych, jak i negatywnych - wskazuje na konieczność łączenia oraz godzenia celów wydajności z potrzebą dbania o dobrostan pracowników. $Z$ tego punktu widzenia kluczowe wydaje się równoważenie wymagań wobec pracowników i ich zasobów, a także pełnionych przez nich ról zawodowych (oraz organizacyjnych). Realizacja tego celu wiąże się m.in. z kształtowaniem dopasowania do pracy oraz jej projektowaniem (podejście top-down), jak również wspieraniem procesu przekształcania pracy (job crafting), stanowiącego autonomiczne działania pracowników (podejście top-up). Ukazuje to, że podejście do pracy (niezależnie od jej charakteru i treści) wymaga nowego spojrzenia, skoro stanowi ona dynamiczny układ zmieniających się zdarzeń, procesów, czynności, umiejscowionych w kontekście, który także ulega przeobrażeniom wskutek zmian w otoczeniu ${ }^{1}$.

Osiąganie zrównoważenia w obszarze wymagań i zasobów oraz dobrostanu pracowników sankcjonuje zatem potrzebę uwzględniania szerokiego zakresu czynników indywidualnych i kontekstowych (ich monitorowania i dopasowywania). To także konieczność zmiany podejścia w kierunku, o jakim pisał Baker (2020), mianowicie personalizacji pracy, w przeciwieństwie do personalizacji produktów lub usług. Sama personalizacja stanowi działanie polegające na zaprojektowaniu lub wyprodukowaniu czegoś, aby spełnić czyjeś indywidualne wymagania (Baker, 2020). W przypadku personalizacji w miejscu pracy również chodzi o indywidualizację działań adresowanych do pracownika, co może pomóc w równoważeniu wymagań i zasobów, biorąc pod uwagę jego specyficzne preferencje, oczekiwania, możliwości. Ponadto istotne są co najmniej dwie ważne zasady, które warto respektować w organizacji - ludzie

1 Dobrym przykładem zachwiania dotychczasowych procesów pracy jest kryzys wywołany przez pandemię, który wpisuje się w teorię systemu zdarzeń (Event System Theory - EST) (Morgeson, Mitchell, Liu, 2015). 
korzystnie oceniają to, co sami mogą zbudować, a ich pozytywne emocje w pracy wzbudza możliwość tworzenia.

Celem artykułu jest charakterystyka wymagań wobec menedżerów i ich zasobów w kontekście funkcjonowania zawodowego oraz sformułowanie rekomendacji w zakresie sposobów ich równoważenia. Analizę i opis przeprowadzono na podstawie zrealizowanych badań jakościowych.

\section{„Przepływ pracy”, czyli wykonywanie pracy jako proces niestabilny, dynamiczny - wymagający stałej regulacji oraz dopasowywania wymagań i zasobów}

Van Veldhoven i Peccei (2015) omawiając zagadnienie dobrostanu w pracy i wydajności, odwołują się do czynników kontekstowych. Autorzy, powołując się na teorię działania (Action Theory), wskazują, że nie akcentuje ona docelowych zachowań pracowników, ale podkreśla wiele rodzajów regulacji związanych z utrzymaniem działań pracowników ukierunkowanych na cele związane z pracą. Wyróżnili bezpośredni kontekst pracy ${ }^{2}$, który tworzą elementy: 1) fizyczne (lokalizacje, maszyny, narzędzia), 2) społeczne (klienci, współpracownicy) oraz niematerialne (skrypty, zlecenia zadań). Autorzy, skupiając się na zasobach energetycznych potrzebnych do wykonywania i regulowania czynności zawodowych, opisują pracę jako strategiczne zachowanie pracownika łączące wszystkie te sytuacyjne nakłady w działania związane z pracą w celu osiągnięcia wydajności, kosztem nakładów związanych z pracą. Wszystkie wyżej wymienione elementy sytuacyjne muszą pasować do charakterystyki pracy, biorąc pod uwagę cele i skoordynowane działania, które są związane z działaniami w pracy (Van Veldhoven, Peccei, 2015). Kluczowe są tu wymagania i zasoby pracownika. Opisuje je teoria wymagań-zasobów (Job Demands-Resources Theory - JD-R) (Bakker, Demerouti, 2007), w ramach której autorzy grupują dwa wskazane czynniki występujące w środowisku pracy i określają, w jaki sposób wymagania i zasoby oddziałują na dobrostan jednostki i jej funkcjonowanie w pracy.

Wymagania definiowane są jako fizyczne, psychologiczne, społeczne i organizacyjne aspekty pracy, które stwarzają konieczność podejmowania fizycznego lub psychologicznego wysiłku (Bakker, Demerouti, 2007). Wymagania, niezależnie od ich charakteru, wiążą się z wkładaniem przez pracownika wysiłku, aby sobie z nimi poradzić, co skutkuje ponoszeniem kosztów emocjonalnych, poznawczych i fizycznych,

2 Oprócz kontekstu bezpośredniego autorzy wymieniają także kontekst dystalny, odnoszący się do środowiska organizacyjnego i społecznego, w którym odbywa się praca. 
które mogą prowadzić do wyczerpania. Natomiast zasoby pomagają pracownikowi radzić sobie $z$ intelektualnymi oraz emocjonalnymi wymaganiami w pracy. Można je podzielić na: 1) organizacyjne, np. praktyki ZZL, 2) relacje interpersonalne, np. atmosfera w zespole, 3) stanowisko pracy, np. udział w podejmowaniu decyzji 4) zadania, np. zróżnicowanie zadań (Bakker, Demerouti, 2007).

Jak podkreślają Van Veldhoven i Peccei (2015), regulacja działań związanych z pracą nie ogranicza się do danych wejściowych sytuacji, ale obejmuje także czynniki wewnętrzne. W konfrontacji z wymaganiami bieżącej pracy „wkład”, jaki uruchamia pracownik, obejmuje aktualny poziom wiedzy, zdolności i umiejętności, a także jego emocjonalny i energetyczny stan. Wszystko to ma istotny wpływ na regulację działań ukierunkowanych na realizację celów. W konsekwencji aktywności związane z pracą nie są statyczne, pracownicy wybierają różne strategie działania nie tylko w zależności od różnic w sytuacyjnych wymaganiach i ograniczeniach, ale także stosownie do wewnętrznych wahań i stanu opisanych wyżej właściwości indywidualnych. Nawet dobrze wykwalifikowany pracownik może na skutek zmęczenia nie wykonywać dobrze swoich zadań. Czynnikiem wysokiego ryzyka zmniejszonej wydajności jest z pewnością eskalacja intensyfikacji pracy, o której pisali Kubicek i Korunka (2017). Intensyfikacja oznacza zapotrzebowanie na pracę wymagającą stałego wysiłku i chociaż może to prowadzić do większej produktywności w krótkim czasie, to jednak w dłuższym okresie skutki dla pracowników są na ogół negatywne. Wśród nich można wymienić: zaburzenia zdrowia fizycznego, wyższy poziom emocjonalnego wyczerpania i niższe zaangażowanie w pracę, a także brak równowagi w diadzie: życie osobiste i zawodowe. Warto jednak zauważyć, że kluczowa dla wystą̧ienia efektu przeciążenia jest sama percepcja wymagań - mogą być one bowiem postrzegane zarówno jako wyzwania (wówczas stymulują zasoby i mobilizują do działania), jak i ograniczenia (w sytuacji oceny braku zasobów) ${ }^{3}$.

Przykładem regulacji działania przez pracownika w obliczu wymagań postrzeganych w kategoriach ograniczeń jest przekształcanie pracy (job crafting). Jedna z jego behawioralnych form - tzw. crafting unikający, opisywany w konceptualizacji Tims i zespołu (2012) w odwołaniu do modelu wymagania-zasoby (Bakker, Demerouti, 2007) zakłada zmniejszanie zaangażowania w czynności zawodowe (np. pomijanie niektórych zadań) i relacji (np. unikanie relacji z trudnym współpracownikiem, klientem). Może to być również wycofywanie się z działania. Odnosząc „przekształcanie pracy od" do ról zawodowych (Bruning, Campion, 2018), pracownik może je ograniczać, co skutkuje zmniejszaniem nakładów pracy i odpowiedzialności za realizowane zadania.

\footnotetext{
3 Podobnie w przypadku wyróżnienia stresorów blokujących i stymulujących. Te ostatnie mogą prowadzić do poprawy efektów zawodowych (LePine, Podsakoff, LePine, 2005; Podsakoff, LePine J.A., LePine M.A., 2007).
} 
Przywołując raz jeszcze model wymagania-zasoby należy stwierdzić, że w pracy oddziałują dwa procesy: energetyczny i motywacyjny (Bakker, Demerouti, 2007). Ten pierwszy uruchamiany jest w efekcie nadmiernych wymagań, które mogą prowadzić do negatywnych skutków na poziomie wydajności i subiektywnego samopoczucia pracownika. Natomiast proces motywacyjny katalizuje zasoby stanowiące bufor dla oczekiwań w pracy, a jednocześnie wspiera zaangażowanie pracownika (Schaufeli, Bakker, 2004). Zasoby umożliwiają efektywne działania nawet w sytuacji wysokich wymagań, neutralizując skutki zdrowotne przeciążenia. Mamy więc do czynienia z dynamiką diady: wymagania-zasoby, której aktualny stan warunkuje wydajność zadaniową i poczucie dobrostanu pracownika.

Powyższe rozważania prowadzą do istotnego wniosku o potrzebie indywidualizacji działań organizacji w zakresie równoważenia wymagań i zasobów z uwagi na wewnętrzny kontekst pracy, określony przez dynamiczny układ właściwości pracowników i zróżnicowanych strategii ich działania. Zrównoważenie wymagań i zasobów z jednej strony jest warunkiem efektywnego działania, z drugiej poczucia satysfakcji z pracy i dobrostanu psychologicznego.

W tym kontekście można wskazać także na zrównoważenie między potrzebami i preferencjami jednostki a tym, co zapewnia praca. Zgodnie z teorią tożsamości pracy (work identity theory) pracownicy mają jedną lub więcej tożsamości pracy, dzięki którym oceniają, czy ich praca jest zgodna z najważniejszymi tożsamościami. Koncepcja siebie oparta na pracy składa się z kombinacji tożsamości organizacyjnych, zawodowych i innych, które kształtują role, jakie przyjmuje pracownik, i odpowiadające im zachowania podczas wykonywania pracy (Walsh, Gordon, 2008). Jak podkreślają Tims, Derks i Bakker (2016), praca, która pasuje do preferowanej przez pracownika tożsamości pracy, może być postrzegana jako interesująca i znacząca, podczas gdy rozbieżności między treścią pracy a tożsamością pracy mogą powodować negatywne doświadczenia zawodowe. Ocena tego obszaru łączy się z rolą zawodową. Pracownicy nie tylko definiują siebie przez pryzmat roli, ale podejmują aktywne działania w obszarze poszerzania bądź zawężania ról w pracy, podobnie jak dzieje się w przypadku zwiększania wyzwań bądź ograniczania wymagań. Działania te mają wpływ na zarządzanie granicami pracy.

Strategie zarządzania granicami pracy mogą się wahać od całkowitej segmentacji pracy i życia osobistego aż po całkowitą integrację (Ashforth i in., 2000). W pierwszym przypadku pracownik stara się wyraźnie oddzielać pracę i rolę zawodową od życia pozazawodowego. Wymiar wysokiej-niskiej segmentacji pracy może się odnosić do sytuacji obiektywnej, gdy pracodawca oczekuje od pracownika np. świadczenia telepracy czy wykonywania pracy zdalnej, co może zaburzać naturalny kontekst oraz wymuszać łączenie ról zawodowych i społecznych. Wówczas - mimo elastyczności, jaką daje taka sytuacja - istnieje duże ryzyko „rozciągania” godzin pracy i zaburzonego 
rytmu odpoczynku i regeneracji. Aspekt subiektywny braku bądź niskiej segmentacji zadań zawodowych dotyczy sytuacji niemożności oderwania się od pracy, przyjmującej postać intencjonalnego realizowania jej po godzinach (tzw. przynoszenia pracy do domu) bądź trudności w psychicznym oderwaniu się od niej w czasie wolnym. Ta ostatnia sytuacja często ma związek z pełnieniem funkcji menedżerskiej. Menedżerowie wykazują stałą gotowość w zakresie dostępności, analizowania problemów związanych z pracą, szczególnie w kontekście złożonych procesów podejmowania decyzji, koordynowania działań, bieżącego reagowania na sytuację i częstej zmiany zadań. Wymogi związane z rolą kierowniczą zwiększają integrację obszarów życia zawodowego i prywatnego, która wyraża się w elastyczności i przepuszczalności granic pracy. Dotyczy to także pracowników, którzy wykonują pracę koncepcyjną bądź twórczą, jak np. pracownicy działów B+R, naukowcy.

W funkcjonowaniu zawodowym menedżerów częste są sytuacje przeciążenia obowiązkami, co dodatkowo nasiliła pandemia. Sytuacja ta jest dobrym przykładem wpływu szerokiego kontekstu na zmiany w zakresie procesów pracy. Wpisuje się ona w przywoływaną już wcześniej teorię systemu zdarzeń (Event System Theory - EST) (Morgeson, Mitchell, Liu, 2015), która zakłada wpływ wydarzeń na organizację, traktowaną jako dynamiczne jednostki o hierarchicznej strukturze ${ }^{4}$. Zmiany wywołane przez pandemię dobrze obrazują uruchamianie procesów przystosowawczych na wszystkich poziomach funkcjonowania (organizacji, zespołów, jednostki), a także transformację i regulację aktywności pracowników związanych z utrzymaniem działań w pracy, czyli to, o czym pisali Van Veldhoven i Peccei (2015). Pandemia nasiliła u menedżerów przeciążenie pracą jako efekt pojawienia się nowych wymagań związanych z przywództwem cyfrowym i potrzebą wypracowania efektywnych sposobów organizowania pracy zdalnej podwładnym oraz monitorowania jej efektów, co wymagało wręcz zmiany stylu zarządzania. Aktywność menedżerów znacząco się zdywersyfikowała i rozszerzyła. Analizę wymagań i zasobów menedżerów uwzględniającą kontekst pandemii zaprezentowano w dalszej części artykułu.

\section{Metodyka badania}

Celem badania jakościowego było pozyskanie wiedzy dotyczącej specyfiki wymagań w pracy menedżerów, z uwzględnieniem sytuacji kryzysu wywołanego przez pandemię, oraz wgląd w posiadane przez nich zasoby. Analiza obszaru zrównoważenia

${ }^{4}$ Wydarzenia wpływają na organizację w przestrzeni i czasie, stają się istotne, gdy są nowe, destrukcyjne i krytyczne. Mogą się pojawiać na dowolnym poziomie hierarchicznym, a ich efekty mogą się rozprzestrzeniać w górę lub w dół całej organizacji. Efektem jest tworzenie nowych zachowań, funkcji i wydarzeń, a wpływ wydarzeń może rozciągać się w czasie (Morgeson, Mitchell, Liu, 2015). 
zasobów i wymagań oraz ról zawodowych uwzględniała odpowiedzi na następujące pytania badawcze:

1. Jaka jest specyfika funkcjonowania zawodowego badanych $z$ uwagi na wymagania zawodowe i zasoby (organizacyjne i podmiotowe) oraz pełnione funkcje?

2. Jaki jest stopień segmentacji pracy i wykorzystywane strategie do „zarządzania granicami pracy"?

3. Jak w związku z kryzysem wywołanym pandemią zmieniły się warunki i sposób wykonywania pracy, zadania i role zawodowe?

4. Jakie strategie i zasoby pozwalają na radzenie sobie $\mathrm{z}$ wyzwaniami?

Badanie miało charakter eksploracyjny z wykorzystaniem częściowo ustrukturyzowanych indywidualnych wywiadów pogłębionych (Individual In-depth Interview - IDI).

Próbę badawczą stanowili menedżerowie $(\mathrm{N}=11)$, reprezentujący zróżnicowane branże, wśród których największy udział miały usługi oraz sektor wysokich technologii.

Wywiady z menedżerami zostały przeprowadzone na postawie scenariusza, który zawierał wątki tematyczne nawiązujące do sformułowanych pytań badawczych. W ramach eksploracji zagadnienia zrównoważenia ról, wymagań i zasobów w pracy poruszono następujące kwestie: zakres i specyfika realizowanych zadań, zmiany warunków pracy jako skutek pandemii, pełnione funkcje organizacyjne, wyzwania związane z kryzysem pandemii, zasoby pozwalające na radzenie sobie z wymogami.

W ramach analizy danych tekstowych pochodzących z transkrypcji przeprowadzono: kodowanie znaczenia, kondensację znaczenia oraz interpretację (Kvale, 2011). Ponadto eksploracja danych uwzględniała - zgodnie z rekomendacją Milesa i Hubermana (2000) - działania związane z ich redukcją i przekształceniami przez selekcję oraz włączanie w ogólne wzory.

Pierwszym etapem były kategoryzacja i kodowanie wypowiedzi respondentów przeprowadzone na podstawie przygotowanego schematu analizy i systemu kodowanych danych, będących pochodną struktury wywiadu. W kolejnym etapie przeprowadzono treściową analizę wypowiedzi badanych menedżerów.

\section{Wyniki badań}

Analiza wypowiedzi respondentów została przeprowadzona na podstawie transkrypcji wywiadów. W tabeli 1 zaprezentowano główne kategorie kodów wraz z przyporządkowaniem odpowiadających im cytatów. Stanowią one ilustrację poruszanych w wywiadzie wątków. 
Tabela 1. Wymagania i zasoby w kontekście funkcjonowania zawodowego menedżerów

\begin{tabular}{|c|c|}
\hline $\begin{array}{c}\text { Jednostka } \\
\text { analityczna }\end{array}$ & Wypowiedź respondenta \\
\hline $\begin{array}{l}\text { Specyfika } \\
\text { pracy } \\
\text { i role } \\
\text { zawodowe } \\
\text { menedżerów }\end{array}$ & 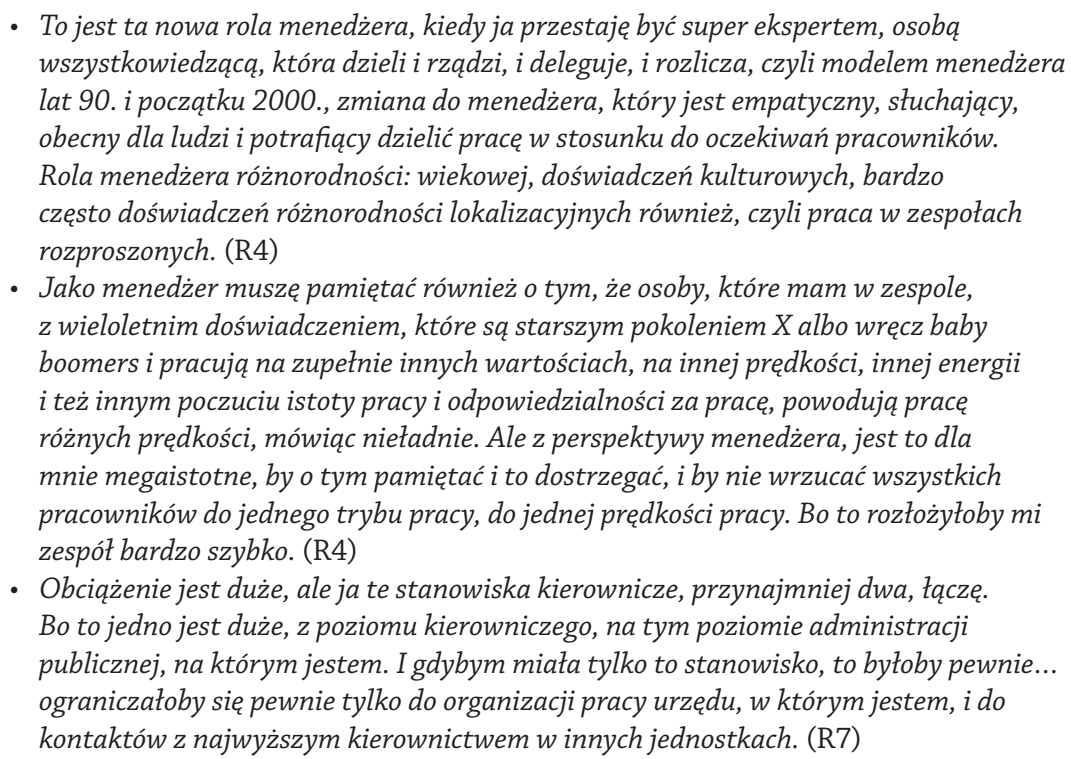 \\
\hline $\begin{array}{l}\text { Wymagania } \\
\text { pracy } \\
\text { w kontekście } \\
\text { roli } \\
\text { kierowniczej } \\
\text { (w tym } \\
\text { w kryzysie } \\
\text { wywołanym } \\
\text { pandemią) }\end{array}$ & $\begin{array}{l}\text { - Wyzwaniem z pewnościa jest tworzenie procedur kontroli czasu pracy. I efektywności } \\
\text { osób korzystających z możliwości pracy zdalnej. Z pewnością trudne jest zbadanie } \\
\text { nastrojów panujących wśród moich podwładnych. Wielu z nich obawia się o przyszłość. } \\
\text { (R3) } \\
\text { - Największym wyzwaniem było utrzymanie kontroli nad procesem. Stworzyłam też } \\
\text { w tym celu odrębne narzędzie, które pozwoliło mi kontrolować proces. Jest to plik, } \\
\text { który umieszczony jest na zdalnym dysku sieciowym, do którego wszyscy mamy } \\
\text { dostęp. Pracownicy byli proszeni o wprowadzanie tam spraw, którymi się zajmujq̨. } \\
\text { (R5) } \\
\text { - Moje obciążenie, chociażby przy tym - praca zdalna: ponieważ nie mieliśmy } \\
\text { mechanizmów, to trzeba je było wymyślić. Stworzyć zarządzenie, uregulować, jak } \\
\text { się komunikujemy z pracownikami, uregulować zabezpieczenie przynajmniej takie } \\
\text { formalne, danych osobowych, bo dane sq wszędzie, tak? Więc obostrzenia. (R7) } \\
\text { - Jeśli chodzi o zarządzanie, to bardzo dobry przykład szedł z góry. I w ogóle, w tej } \\
\text { pandemii bardzo ważne jest, by liderzy szybko przekazywali, od góry, od mojego } \\
\text { szefa idac, i ja dalej do zespołu - że ok, pracujemy dalej, ale jesteśmy świadomi } \\
\text { sytuacji i tego, że każdy może mieć różnq sytuację życiowq. Ja więc wykazywałam } \\
\text { się otwartościqą i dużym zaufaniem do moich pracowników, i taka ogromną tolerancja } \\
\text { i zrozumieniem. Że wiem, że różne rzeczy mogą się dziać, że jest to dla mnie ok, że } \\
\text { w ciagu dnia i pracy mogą się wyłq̨czyć. (R15) }\end{array}$ \\
\hline
\end{tabular}




\begin{tabular}{|c|c|}
\hline $\begin{array}{c}\text { Jednostka } \\
\text { analityczna }\end{array}$ & Wypowiedź respondenta \\
\hline $\begin{array}{l}\text { Wyzwania } \\
\text { i utrudnienia } \\
\text { związane } \\
\text { z pracą } \\
\text { zdalną } \\
\text { w kryzysie } \\
\text { wywołanym } \\
\text { pandemią }\end{array}$ & $\begin{array}{l}\text { - W mojej instytucji pracę utrudniło. Bo placówka była nieprzygotowana totalnie, tzn. } \\
\text { jednostka, w której pracuje, nie daje możliwości pracy zdalnej na co dzień, w zwiq̨zku } \\
\text { z czym ciężko było przejść na pracę zdalnq̨ nagle. Tzn. nie ma laptopów, które można } \\
\text { zabrać do domu. Także praca była skomplikowana, bo każdy musiał zorganizować się } \\
\text { we własnym zakresie, jeżeli chodzi o sprzęt. (R1) } \\
\text { - Praca zdalno-rotacyjna jest bardziej obciążająca. Placówka, w której pracuje, jest } \\
\text { takim typowym tworem biurokratycznym, nastawiona na formę papierowa. I przy } \\
\text { pracy zdalnej ciężko jest z tej formy papierowej zrobić zestawienia itd., bo nie } \\
\text { można tego ominąć. Tutaj wszystko musi mieć swój bieg - mamy ten program, obieg } \\
\text { dokumentacji papierowo-programowy i to było trudne. (R1) } \\
\text { - Na pewno są obszary, gdzie ich było dużo więcej. Problemem było w mojej instytucji } \\
\text { nieprzygotowanie się na pracę zdalnq. Czyli brak sprzętu. I brak rozwiq̨zań, takich jak } \\
\text { podpis elektroniczny czy elektroniczny obieg dokumentów. (R2) } \\
\text { - Ten pierwszy zachwyt tych kilku tygodni był absolutnie fantastyczny, tylko że on } \\
\text { potem przerodził się, no wajcha przeskoczyła w druga stronę. Bo nagle się okazało, że } \\
8 \text { h na zoomie to jest po prostu fizycznie nie do wysiedzenia. Bo kręgostup boli, bo oczy } \\
\text { bola, bo już po } 2 \text { h któregośs spotkania nie jesteśmy w stanie aktywnie uczestniczyć, } \\
\text { po prostu jesteśmy zmęczeni, zarówno emocjonalnie, jak i fizycznie. (R4) }\end{array}$ \\
\hline $\begin{array}{l}\text { Wyzwania } \\
\text { i utrudnienia } \\
\text { związane } \\
\text { z kryzysem } \\
\text { pandemii } \\
\text { - relacje } \\
\text { społeczne }\end{array}$ & 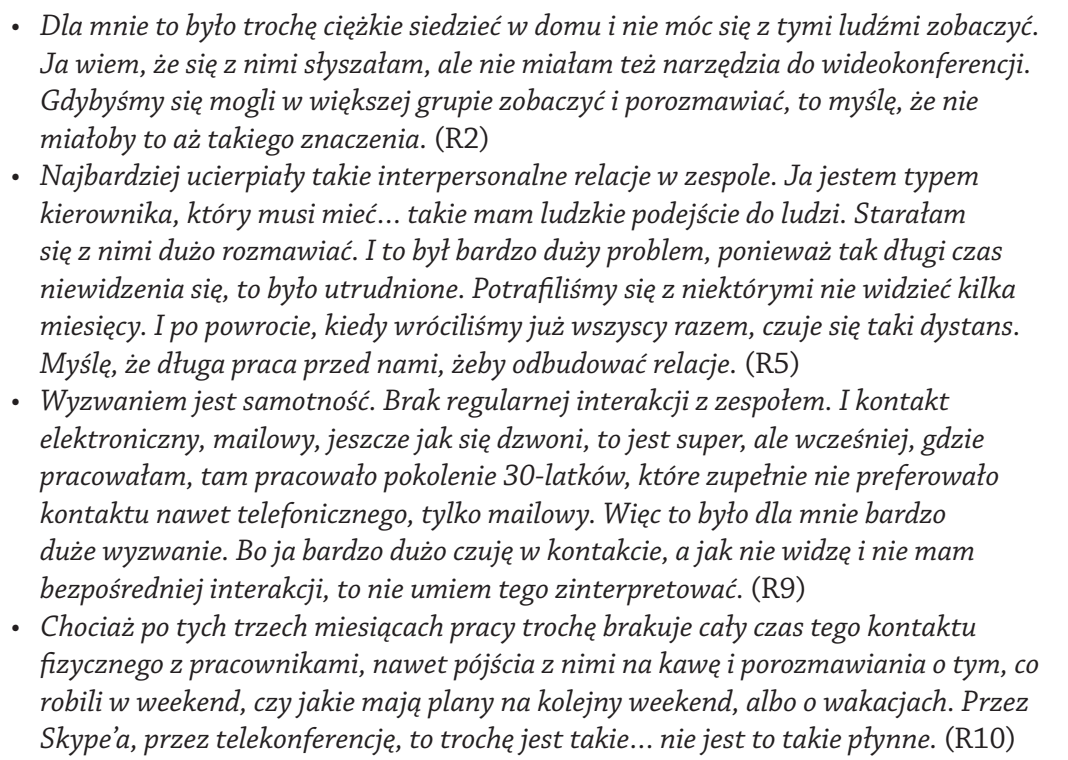 \\
\hline $\begin{array}{l}\text { Segmentacja } \\
\text { vs integracja } \\
\text { pracy/ } \\
\text { granice pracy }\end{array}$ & $\begin{array}{l}\text { - Czy przeszkadza, że praca i życie się zlewają? I tak i nie, ale nie potrafię odpowiedzieć, } \\
\text { czy to jest in plus, czy in minus. Bo dzień się wydłużyz, człowiek jest dłużej w pracy, } \\
\text { ale za to jest w niej wtedy, kiedy chce, a przynajmniej w jakiejś części dnia. Czasem } \\
\text { można zaczą́ o } 10 \text { czy } 11 \text { - ok, jeśli nie było wcześniej jakiegoś spotkania czy niczego } \\
\text { terminowego - no ale to oznacza, że albo praca musi być zrobiona, albo ja do drugiej } \\
\text { części mojej pracy siądęo } 21 \text { i z tym jestem ok. Bo to jest moja decyzja. (R4) }\end{array}$ \\
\hline
\end{tabular}




\begin{tabular}{|c|c|}
\hline $\begin{array}{c}\text { Jednostka } \\
\text { analityczna }\end{array}$ & Wypowiedź respondenta \\
\hline & 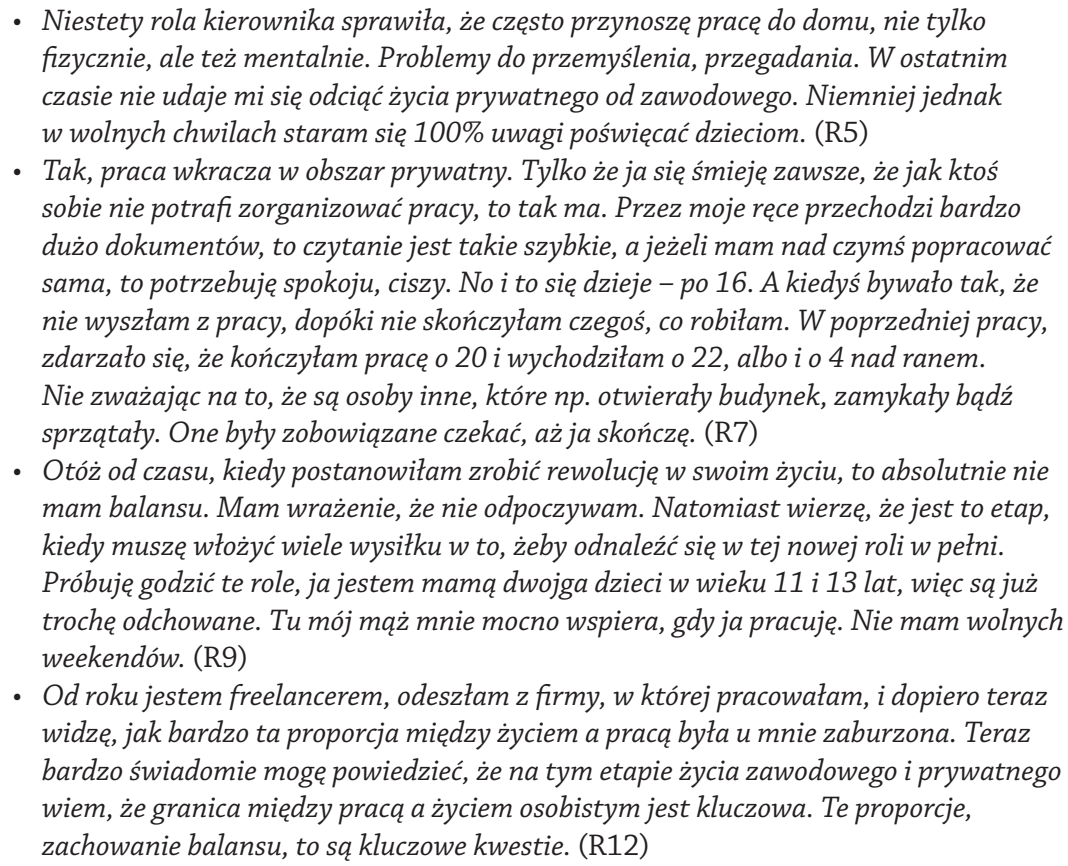 \\
\hline $\begin{array}{l}\text { Zasoby } \\
\text { - dostępność } \\
\text { i deficyty }\end{array}$ & $\begin{array}{l}\text { - Wyznaję regułę, że co nas nie zabije, to nas wzmocni. Z każdego kryzysu wychodzi } \\
\text { się silniejszym. I tak będzie i teraz. Nie zamierzam korzystać z porad psychologa czy } \\
\text { specjalnych terapii. Wybieram relaks na tonie natury w gronie rodziny. Myśle, że taki } \\
\text { czas z dala od pracy i obowiazków jest cenny. (R3) } \\
\text { - Zasobów ilościowo pewnie jest tyle samo albo nawet może być mniej, no bo jest } \\
\text { kwestia oszczędzania i optymalizacji, ale jeśli chodzi o jakość wykorzystania zasobów, } \\
\text { to korzystamy w tej chwili ze znakomicie innych narzędzi i kompetencji, czy bardziej } \\
\text { postaw i kompetencji, niż te, których ja się uczyłem jeszcze paręnaście lat temu. (R4) } \\
\text { - Wcześniej sądzitam inaczej, teraz myśle, że mogę powiedzieć, że odporność jest } \\
\text { catkiem wysoka. Wtedy, kiedy muszę, kiedy ludzie patrzq i ludzie polegają na mnie } \\
\text { - nie pozwalam sobie na moment stabości. Te momenty przychodzq później, kiedy } \\
\text { jestem sama i nikt nie patrzy. Kiedy mam być - może to za mocne słowo - liderem dla } \\
\text { zespołu, staram się nim być. I swoich lęków i słabości nie przelewać na zespót. (R5) } \\
\text { - Patrzqc na mój konstrukt osobowościowy, to ja mam w sobie bardzo dużo takiego } \\
\text { naturalnego spokoju. I trudno jest mnie wyprowadzić z równowagi, co działało o tyle } \\
\text { dobrze na zespót, że działałem trochę jako element tonujący emocje. (R4) } \\
\text { - Nie analizowałem tego, ale na pewno jestem bardzo odporny psychicznie. Tak. Staram } \\
\text { się tego ciężaru odporności psychicznej nie zrzucać na pracowników. To jest ważne, że } \\
\text { nie zrzucam na nich odpowiedzialności, że coś jest trudne do zrobienia. (R6) }\end{array}$ \\
\hline
\end{tabular}

Źródło: opracowanie własne na podstawie danych jakościowych. 


\section{Wnioski z badań}

Przeprowadzona analiza wypowiedzi respondentów pozwoliła nakreślić obraz funkcjonowania zawodowego menedżerów, biorąc pod uwagę wymagania i zasoby w miejscu pracy. Wnioski należy formułować z uwzględnieniem specyfiki pracy menedżerów i wyzwań, jakie łączą się z tą rolą.

Główne konkluzje płynące z analizy treści wywiadów wskazują na to, że:

- zmienia się rola lidera, którego zadaniem jest łączenie nastawienia na zadania i ludzi, jednocześnie respektowanie różnorodności pracowników, a przy tym wykazywanie elastyczności w podejściu do nich. Funkcjonowanie w warunkach złożoności, niepewności i konieczność szybkiego podejmowania decyzji wymagają otwartości, zwinnego zarządzania. Kluczową rolę w relacjach z podwładnymi odgrywa zaufanie. Pojawia się konieczność rozwiązania paradoksu autonomia - kontrola. Drogą do osiągnięcia tego celu może być partycypacja decyzyjna,

- dynamika zmian w wykonywaniu zadań wywołana przez pandemię implikuje coraz większą personalizację pracy - „menedżer różnorodności” musi ją stosować zgodnie z oczekiwaniami pracowników, wsłuchując się w ich potrzeby, a także respektując indywidualną sytuację każdego pracownika,

- pojawiły się wyzwania wynikające z pandemii - przeciążenie pracą na skutek jej intensyfikacji oraz konieczność wypracowania efektywnych sposobów kontroli pracowników i organizowania pracy zdalnej, a także pozyskiwanie zasobów organizacyjnych, często bardzo podstawowych dla realizacji zadań zawodowych, np. sprzętu,

- wystąpiły problemy związane ze zmianą organizacji pracy, która w dużym stopniu przyjęła formę zdalną. Z jednej strony praca zdalna stwarza nowe możliwości, z drugiej wkracza w obszar życia prywatnego, a także jest źródłem deprywacji społecznych potrzeb zarówno pracowników, jak i menedżerów. Ci ostatni lokują większą ilość czasu w indywidualne kontakty z pracownikami w związku z pracą poza biurem, a także koniecznością organizowania pracy, pozyskiwania zasobów organizacyjnych i tworzenia nowych procedur pozwalających monitorować „przepływ pracy”,

- wzrosło znaczenie relacji społecznych i bezpośredniego komunikowania się w sieciach komunikacji pionowej i poziomej, istotnych dla pełnego rozumienia intencji i naturalnych kontaktów w miejscu pracy, a także wydajności kontekstualnej,

- znaczenia nabrała segmentacja pracy dla zachowania poczucia dobrostanu i zrównoważenia sfery życia prywatnego i aktywności zawodowej. Większa integracja tych dwóch obszarów (a co za tym idzie, niższy poziom dobrostanu) jest widoczna u menedżerów, których granice pracy są „rozciągnięte”, zaś work-life balance wyraźnie zaburzony, 
- niezbędne stały się zasoby do realizowania wymagań zadaniowych. Ich źródło to zarówno predyspozycje osobowościowe, jak i relacje społeczne, kluczowe dla poczucia dobrostanu psychologicznego i efektywnej współpracy w miejscu pracy.

\section{Podsumowanie}

Zrównoważenie w pracy wymagań i zasobów, biorąc pod uwagę dynamikę zmian zarówno samego kontekstu pracy, jak i przeobrażeń w sposobie jej wykonywania, wymaga zmiany podejścia w organizacjach - ze standaryzacji na większy poziom personalizacji pracy. Baker (2020) wymienia cztery czynniki, które wyjaśniają lub bezpośrednio wpływają na to, dlaczego ludzie cenią personalizację: 1) dopasowanie preferencji, 2) osiągnięcia, 3) inwestycja wysiłku, 4) tworzenie. I chociaż wszystkie są istotne, to z uwagi na zakres tematyczny artykułu warto odnieść się do tego pierwszego, szczególnie że respondenci w ramach przeprowadzonych wywiadów jakościowych wskazywali, iż stawiane im wysokie wymagania często determinują czynniki kontekstowe związane z organizacją, które uniemożliwiają im autonomiczne podejmowanie decyzji czy też elastyczne reagowanie, nie mówiąc już o braku dostępu do zasobów organizacyjnych.

W zakresie dopasowywania preferencji pracownika należy wskazać nie tylko na oczywistą zgodność pomiędzy wymaganiami na stanowisku pracy a kompetencjami pracowników. Dopasowanie oznacza również branie pod uwagę preferencji w zakresie sposobu i warunków realizacji zadań zawodowych. Wywiady z menedżerami ukazały ich przeciążenia jako skutek wysokich wymagań, których eskalację obserwujemy w związku z kryzysem wywołanym pandemią. Dla nich oznacza ona konieczność realizacji nowych zadań oraz wyzwań przywództwa cyfrowego. W tej sytuacji równoważenie wymagań i zasobów implikuje: 1) wsparcie w zakresie realizacji dodatkowych zadań, 2) działania ukierunkowane na odnawianie zasobów fizycznych i psychicznych menedżera. Może to zapobiegać sytuacji kumulowania reakcji obciążenia, które zgodnie z teorią wysiłku-regeneracji (effort-recovery theory) prowadzą do negatywnych skutków (Meijman, Mulder, 1998).

Wobec nowych wymogów rewizji wymaga sam kontekst, w którym wykonywana jest praca. Chodzi tu chociażby o postulowane przez badaczy wyjście poza modele charakterystyki pracy zawierające jedynie ogólne zestawy cech pracy, powiązane z dobrostanem i wydajnością pracownika. Van Veldhoven i Peccei (2015) rekomendują raczej modele uwzględniające wiele poziomów determinant, rozszerzoną listę cech pracy oraz wiele poziomów rezultatów, połączonych z dużą liczbą mechanizmów i procesów, które je moderują. Przykładem może być tu nowe spojrzenie na miejsce wykonywania pracy. W kontekście zmian w zakresie organizacji pracy i przejścia na pracę 
zdalną nowego znaczenia nabierają przestrzeń pracy i czas realizowania obowiązków zawodowych. W przypadku menedżerów, jak i pracowników, praca zdalna wywołana pandemią zaburzyła równowagę praca-życie i w wielu przypadkach obniżyła poczucie dobrostanu psychologicznego, pomimo benefitu odzyskanego czasu - wcześniej przeznaczanego na dojazdy. Ciekawym przykładem dotyczącym personalizacji przestrzeni pracy są badania, w których Laurence, Fried, Slowik (2013) wykazali, że łagodzi ona wpływ niskiego poziomu odczuwanej prywatności na występowanie wyczerpania emocjonalnego. Na doświadczanie prywatności wpływa architektura, która ją zapewnia - jej wpływ na wyczerpanie emocjonalne jest moderowany przez personalizację osobistego obszaru pracy (ilość rzeczy osobistych w miejscu pracy). Wyższy poziom personalizacji zmniejsza niekorzystny wpływ niskiego poziomu prywatności na emocjonalne wyczerpanie. W przypadku menedżerów kluczowa jest aranżacja przestrzeni w pracy umożliwiająca radzenie sobie z dużym wysiłkiem systemu poznawczego - szczególnie zasobów uwagi, mobilizowanej i dzielonej na wiele czynności związanych z koordynowaniem pracy podwładnych.

Z punktu widzenia działań na poziomie całej organizacji, które mogą sprzyjać personalizacji, a co za tym idzie lepszemu równoważeniu wymagań i zasobów, ważne jest systematyczne badanie nie tylko cech pracy, ale zapotrzebowania na określony rodzaj pracy, biorąc pod uwagę homogeniczne grupy pracowników z konkretnych specyficznych środowisk (Van Veldhoven, Peccei, 2015). Pozwola to dopasować rodzaj określonych praktyk. Jako przykład można podać specyfikę pracy w firmach sektora usług wiedzochłonnych (knowledge-intensive business services sector - KIBS). Badania dotyczące związku praktyk HR z produktywnością pracowników wiedzy tworzących usługi spersonalizowane na klientów ukazały, że najsilniej łączy się ona z projektowaniem i właściwościami pracy oraz partycypacją i autonomią (Wojtczuk-Turek, 2017). Można zatem powiedzieć, że w kontekście specyfiki pracy opartej na wiedzy w firmach KIBS działania związane z kreowaniem różnorodnych zadań i wzbogacaniem pracy, wysokim wymogiem kreatywności oraz koniecznością wykorzystywania różnorodnych umiejętności przy jednoczesnym zapewnieniu swobody działania i realizacji idei podmiotowego traktowania pracowników, sprzyjają zarówno ekspresji pożądanych zachowań organizacyjnych (innowacyjnych, proaktywnych i prospołecznych), jak i osiąganiu rezultatów. Wiedza o specyficznym kontekście pracy i preferencjach pracowników może pomóc w równoważeniu stawianych im wymagań poprzez dostarczanie zasobów organizacyjnych oraz rozwijanie podmiotowych. W odniesieniu do tych drugich warto poczynić jeszcze jedną uwagę. Jest ona związana z oddziaływaniem w diadzie: lider-podwładny i dotyczy indywidualizacji interwencji oraz adresowania ich do właściwych osób. Nie wszyscy pracownicy wymagają jednakowo silnych oddziaływań ze strony lidera. Badania pokazują, że działanie praktyk HR, jak i wpływ przywództwa są szczególnie istotne 
w odniesieniu do pracowników z niskim poziomem przekonania o własnej skuteczności (self-efficacy) (Wojtczuk-Turek, 2016). Osoby o wysokim poziomie tego zasobu wchodzącego w skład kapitału psychologicznego nie potrzebują tak dużego wsparcia lidera w miejscu pracy, gdyż bardzo dobrze radzą sobie z wymaganiami i przeszkodami w pracy. Można zatem stwierdzić, że indywidualizacja oddziaływań menedżera przynosi korzyści nie tylko beneficjentom tych działań, czyli pracownikom, ale także samemu liderowi - pozwalając mu zachować większe zrównoważenie w obszarze wymagań i zasobów w kontekście jego społecznej aktywności i efektywnie kształtować relacje z innymi w miejscu pracy. Relacje oparte raczej na zaufaniu i odpowiedzialności oraz zachętach do przekształcania pracy przez podwładnych, a nie silnej kontroli, o której mówili w wywiadach respondenci. Wymaga to jednak zmiany mentalnej menedżerów, a na poziomie działań organizacji zmian w zakresie procedur i standardów funkcjonowania - przechodzenia z poziomu top down do promowania inicjatyw oddolnych i stwarzania pracownikom warunków do autonomii - oczywiście w zakresie zgodnym $\mathrm{z}$ ich indywidualnymi preferencjami.

\section{Bibliografia}

Ashforth, B.E., Kreiner, G.E., Fugate, M. (2000). All in a Day's Work: Boundaries and Micro Role Transitions. Academy of Management Review, 25(3), 472-491.

Baker, R. (2020). Personalization at Work. How HR Can Use Job Crafting to Drive Performance, Engagement and Wellbeing. New York: Kogan Page.

Bakker, A.B. Demerouti, E. (2007). The Job Demands-Resources Model: State of the Art. Journal of Managerial Psychology, 22(3), 309-328.

Boyd, C.M., Hayward, R.M., Tuckey, M.R., Dollard, M.F., Dormann, Ch.H. (2015). Emotion Work in Service Occupations. Links to Well-being and Job Performance. W: M. Van Veldhoven, R. Peddei (red.), Well-being and Performance at Work. The Role of Context, New York: Psychology Press, 55-74.

Bruning P., Campion M. (2018), A Role-resource Approach-avoidance Model of Job Crafting: A Multi-method Integration and Extension of Job Crafting Theory. Academy of Management Journal, 61(2), 499-522.

Kubicek, B., Korunka, Ch. (2017). Job Demands in a Changing World of Work. W: R.J. Burke, K.M. Page (red.), Research Handbook on Work and Well-Being, Cheltenham: Edward Elgar Publishing, 59-76.

Kvale, S. (2012). Prowadzenie wywiadów. Warszawa: Wydawnictwo Naukowe PWN.

Laurence, G.A., Fried, Y., Slowik, L.H. (2013). "My Space”: A Moderate Mediation Model of the Effect of Architectural and Experienced Privacy and Workspace Personalization on Emotional Exhaustion at Work. Journal of Environmental Psychology, 36, 144-152. 
LePine, J. A, Podsakoff, N.P., LePine, M.A. (2005). A Meta-analytic Test of the Challenge Stressor Hindrance Stressor Framework: An Explanation for Inconsistent Relationships among Stressors and Performance. Academy of Management Journal, 48, 764-775.

Miles, M.B., Huberman, A.M. (2000). Analiza danych jakościowych. Białystok: Trans Humana.

Meijman T.F., Mulder G. (1998). Psychological Aspects of Workload. W: P.J.D. Drenth, H. Thierry (red.), Handbook of Work and Organizational Psychology, Hove UK: Psychology Press, 5-33.

Morgeson, F.P., Mitchell, T.R., Liu, D. (2015). Event System Theory: An Event-Oriented Approach to the Organizational Sciences. Academy of Management Review, 40(4), 515-537.

Murphy K., Tierney W. (2020). What Has Changed and What Has Not?. W: B. Hoffman, M. Shoss, L. Wegman (red.), The Cambridge Handbook of the Changing Nature of Work, Cambridge: Cambridge University Press, 42-66.

Podsakoff, N.P., LePine, J.A., LePine, M.A. (2007). Differential Challenge Stressor - Hindrance Stressor Relationships with Job Attitudes, Turnover Intentions, Turnover, and Withdrawal Behavior: A Meta-analysis. Journal of Applied Psychology, 92, 438-454.

Romanowska, M., Cygler, J. (red.) (2014). Granice zarzq̨dzania. Warszawa: Oficyna Wydawnicza SGH.

Schaufeli, W.B., Bakker, A.B. (2004). Job demands, Job Resources and their Relationship with Burnout and Engagement: A Multi-sample Study. Journal of Organizational Behavior, 25, 293-315.

Tims, M., Derks, D., Bakker, A.B. (2016). Job Crafting and its Relationship with Person-job Fit and Meaningfulness: A Three-wave Study. Journal of Vocational Behavior, 92, 44-53.

Van Veldhoven, M., Peccei, R. (2015). Contextualizing Individual Well-being and Performance at Work. W: M. Van Veldhoven, R. Peccei (red.), Well-being and Performance at Work. The Role of Context, New York: Psychology Press, 1-14.

Walsh, K., Gordon, J.R. (2008). Creating an Individual Work Identity. Human Resource Management Review, 18, 46-61.

Wojtczuk-Turek, A. (2016). Wspieranie produktywności pracowników wiedzy. Rola zarzqdzania zasobami ludzkimi i dopasowania człowiek-organizacja. Warszawa: Wydawnictwo Naukowe PWN.

Wojtczuk-Turek, A. (2017). In Search of Key HR Practices for Improvement of Productivity of Employees in the KIBS Sector. Contemporary Economics, 11(7), 5-16. 


\begin{abstract}
How to Balance Demands and Resources at Work and Establish Boundaries? - on the Need for Personalisation in The Work of Managers

The aim of the paper is to characterize managers' demands and resources in the context of their professional functioning and formulate recommendations on the ways in which these areas can be balanced. The analysis and descriptions were conducted on the basis of qualitative studies on representatives from companies of various sizes and from a number of industries. On the basis of qualitative in-depth interviews (IDI), changes in the role of the leader were observed. Leaders are expected to combine a variety of roles, and they need to act flexibly, demonstrating high integration of boundaries between private and professional spheres of functioning, which results in lowered life-work balance and high demand of overload at work. Recommendations were formulated as to increasing work personalization as a way to improve job-preferences fit and facilitate achievement of demands/resources balance.
\end{abstract}

Keywords: demands, resources, work-life balance, personalization at work

\title{
Dr hab. Agnieszka Wojtczuk-Turek, prof. SGH
}

Profesor uczelni w Instytucie Kapitału Ludzkiego Szkoły Głównej Handlowej w Warszawie. Kieruje Instytutem Kapitału Ludzkiego oraz Zakładem Zachowań Organizacyjnych. Specjalizuje się w problematyce zachowań organizacyjnych, kreatywności i innowacyjności, kompetencji i postaw wobec pracy, przywództwa, zarządzania kapitałem ludzkim, dopasowania do organizacji. W tych obszarach kierowała projektami badawczymi m.in. w ramach grantów naukowych Narodowego Centrum Nauki oraz projektów unijnych realizowanych w ramach EFS. Autorka blisko 100 artykułów naukowych i czterech monografii. Członkini Academy of Management, European Academy of Management, Eurasia Business and Economics Society, Polskiego Stowarzyszenia Psychologii Organizacji. Prowadzi zajęcia na studiach podyplomowych, doktoranckich i MBA.

e-mail: awojtc@sgh.waw.pl

ORCID: 0000-0002-5384-4181 